Kitula King'ei

\title{
HISTORICAL AND FOLKLORIC ELEMENTS IN FUMO LIYONGO'S EPIC
}

This is a copy of the article from printed version of electronic journal

\author{
Folklore Vol. 16
}

ISSN 1406-0957

Editors Mare Kõiva \& Andres Kuperjanov

Published by the Folk Belief and Media Group of ELM

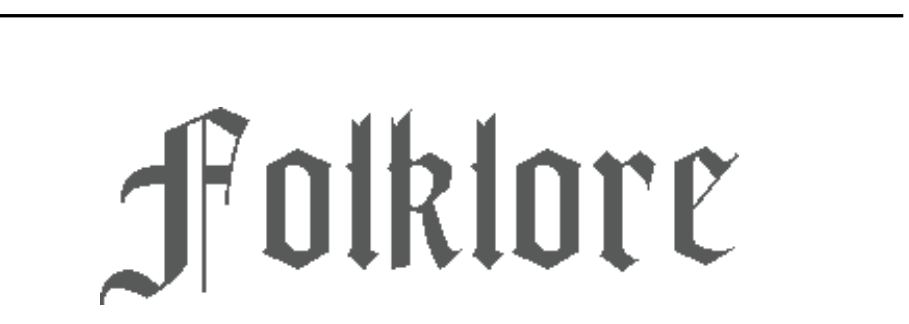

\section{Electronic Journal of Folklore}

Electronic version ISSN 1406-0949 is available from http://haldjas.folklore.ee/folklore

It's free but do give us credit when you cite!

(C) Folk Belief and Media Group of ELM, Andres Kuperjanov

\section{Tartu 2001}




\section{HISTORICAL AND FOLKLORIC ELEMENTS IN FUMO LIYONGO'S EPIC}

\section{Kitula King'ei}

\section{INTRODUCTION}

There is general agreement among the leading critics of classical Kiswahili poetry that "The earliest known Swahili poet of note is Fumo Liyongo, who is dated by various writers anywhere from the 14th to the 17th century" (Allen 1971: 6). The Kiswahili epic Utenzi wa Liyongo was first popularised by Liyongo through lyrics for gungu dance (Knappert 1979: 64-66).

The early scholars (Edward Steere, Freeman Geenville, James Kirkman, Alice Werner, William Hichens, etc.; see Knappert 1979: 64-66) who researched Liyongo's poetry and life have presented fairly different accounts concerning the work and life of this Swahili bard. Liyongo's epic is said to have been recorded first in the Arabic script in around 1880 by Muhammad Bin Bakari Kijumwa (his full name being Muhammad Bin Abubakar Bin Umar al-Bakari) from Malindi who died around 1913. This is also the version of the epic that is commonly known, and that was published in 1964 by Ali Jahadhmy. According to Harries (1962), the manuscript contains the famous Song of Saada found also in other manuscripts as well as gungu songs known in many Swahili communities in NorthKenya.

The current paper is an attempt to understand and describe both the historical and folkloric aspects of this famous Kiswahili epic with the aim of highlighting the similarities and differences between Liyongo the historical figure and Liyongo the figure of creative art with legendary, mythical abilities attributed to heroes of oral tradition. 


\section{SUMMARY OF THE STORY}

The variation of detail in the main story notwithstanding, the gist of the story is an account of how Fumo Liyongo struggled with Daudi Mringwari, the Sultan of Pate who was Liyongo's maternal cousin. Mringwari viewed the poet as a potential usurper to his throne while Liyongo was convinced that he was the rightful heir to the kingdom. Thus the succession of the throne of Pate Sultanate forms the core of the story.

Mringwari makes several attempts to get rid of Liyongo. First Mringwari arranges a marriage between Liyongo and a beautiful Galla woman hoping to keep the bard in Galla county far from the city of Pate. After his adversary settles down, the ruler offers a reward to the Sanye (or Boni) and Dahalo tribesmen for Liyongo's head. However, Liyongo outwits them in their plan to shoot him.

Next the Sultan asks his henchmen to persuade Liyongo to return to Pate city where he is captured and imprisoned. But the prisoner manages to obtain a file with which he cuts the chains and walks out to freedom. The Sultan is too scared to re-arrest him and almost at loss what action to take to solve the Liyongo problem which had now turned into a complete nightmare.

Then Mringwari plots to kill Liyongo by the hand of none other than Liyongo's beloved son whose mother is his Galla wife. He buys the would-be assassin's loyalty and cooperation with the promise of royal treatment and his daughter. The son cunningly extracts the secret of the weapon that could kill Liyongo. Liyongo becomes convinced that his son has been bought by his enemies, he rebukes and curses him but the lad goes on with his devilish mission.

With the secret weapon, a copper dagger, the son stabs his sleeping father. Liyongo manages to arm himself and chases his attacker to a village well where he remains in a kneeling position with his bow and arrows aimed at his fleeing attacker for three days. The whole village goes into mourning when, on the third day, the poet's mother discovers that Liyongo was actually dead. 


\section{THE PROBLEM}

The task of differentiating the legendary from the historical in a folklore composition is not an easy one as the two are intrinsically intertwined and inseparably bound. Yet, in such forms as epic poetry, the reader and the critic must apply some rules or formulas in order to delineate the two levels to some extent in order to explain the application of formal rules and attributes of a folk narrative in the development of the genre. The current article attempts to achieve this by looking at the literary tools used in the composition of the Liyongo epic to create the character of the hero on the one hand, and the fusion of the historical account in the narrative, on the other.

According to Cohen (see Dundes 1965), reconstructing historical reality in an oral text such as Utenzi wa Liyongo may be viewed as a process constituting three levels of analysis, namely:

(a) the ethnological level treating literature as a direct representation of the human society with its cultural values, attitudes and practices. From this aspect, human literary characters such as Fumo Liyongo are creations of culture and represent typical members of the Waswahili of Kenya's northern coast. In line with this view, Fumo Liyongo may be regarded as a folk hero who portrays such desirable virtues as courage, humility and a drive for justice and fairness;

(b) the cognitive level regards literature as the thought process of human beings individually and collectively. This level concerns philosophical and abstracted ideology and ignores empirical dimensions of literary representation. A close reading of Liyongo's epic reveals the fact that the Swahili community this epic originates from cherish the notion of the dignity of struggle for the ideals that one believes in and holds dear even to the point of making the ultimate sacrifice;

(c) the taxonomic level concentrates on observable units of reality (or motifs) and relationship between these units. In the Liyongo epic, for instance, these include the royalty, the aspiring ruler (Liyongo), the subjects, parents and their children (Okpewho 1983: 1). 


\section{ANALYSIS OF HISTORICALAND FOLKLORIC ELEMENTS}

\section{The Historical Dimension}

It is a fact that no mention of Liyongo is found in Swahili historical chronicles (Harries 1962: 49). However, Liyongo is alive in the oral tradition which repeatedly mentions the hero's association with the citadel of Shagga. About the place of his birth, the epic states:

Ya Liyongo hutwambia

Siu alikizaliwa

Pate alikitembea

Kwa Mwana akafilia

(Knappert 1979: 67)
About Liyongo they tell us

In Siu he was born

Pate he visited

And he died at Kwa Mwana

Shagga (or Shaka) appears in a number of old Arab charts as a richly populated area east or south-east of Faza island. Oral tradition places Shagga city on Pate island before the 13th century. Most probably, Shagga is identical to Shungwaya, a Bantu settlement founded around the 7th century (c. 689). This is the traditional habitation area of the Swahili and other coastal and highland Bantus according to many historians (see Were 1971).

The physical attributes of Liyongo are also described in detail with the aim of depicting his masculinity and exceptional physique.

Kimo kawa mtukufu

Mpana sana mrefu

Majimbo kawa maarufu

Watu huja kwangaliya

Ni mwanamume sahihi

Kama simba una zihi

Usiku na asubuhi

Kutembea ni mamoja

Ghafla kikutokeya

Mkojo hukupoteya

Tapo likakuiliya

Ukatapa na kuliya
He was of glorious stature

Very broad and tall

He became famous in the countryside

And people came to look at him

He was a real man

Strong as a lion

Be it night or day

He freely moved about

If he suddenly appeared to you

You would wet yourself with fright

You would start trembling

You would tremble as you cry out 
Mato kikukondoleya

Ghafla utazimiya

Kufa kutakurubiya

Kwa khaufu kukungiya

(Harries 1962: 52-55)
If he focused his eyes on you

You would faint from fear

You would stare death in the face

As fear would grip you

To further amplify Liyongo's unmatched physical strength, the epic states how Liyongo would complete in giant strides a journey that would have taken ordinary people several days. For instance, the poet traveled from Shaka to Pate city, a journey of four days, in exactly two days. In addition, he could shoot and bring down a whole fruit-bearing branch of the mkoma-tree without having to climb to the top of the massive tree, which also serves to emphasize the enormous size of the poet.

Perhaps the most telling quality of the personality of Liyongo is his skill and great talent in composing and singing the poetic songform gungu. For example, in jail Liyongo used this skill to send a message to his mother asking for the file that he eventually used to cut the chains to free himself. Liyongo sang thus:

Ewe kijakazi nakutuma Hujatumika kamwambie mama

Ni muinga hajalimuka

Afanye mkate pale kati

Tupa kaweka nikezee pingu

Na minyoo ikinyemuka

Nitatage kuta na madari

Yakiyepuka niue rijali Nao wakiwana hiteka

Ningie ondoni ninyepee Ja mwana nyoka niingie mwituni
You maid, I sent you

You still don't understand

Tell my mother who still is ignorant

Let her make me a loaf and put a file inside it

So that I can cut these handcuffs

And free myself of these chains

So that I can cross walls and roofs and break them

Let me kill men

And laugh at them as they fight back

Let me go into the reeds

And creep like a fierce snake 
Let me enter the forest and roar like a fierce lion

(Harries 1962: 52-55)

The epic of Liyongo establishes not just the human characteristics of the legendary figure but also the fact of his real existence among his people, the Waswahili of Pate whose neighbours were the Pokomo (Boni) and the Wagalla. These communities still live in the same geographical area as they did many centuries ago before the composition of the epic. Liyongo was a popular hero for championing the cause of his people and defending them at times of danger as the epic states. It is also easy to confirm that these people were already islamised at the time of the composition of the epic: when Liyongo remained by the side of the village well, the villagers did not get water that they needed for the mandatory cleansing before prayers.

\section{The Folkloric Dimension}

According to Dundes (1965) epic compositions such as Utenzi wa Liyongo exhibit some formal and thematic attributes including the above-mentioned mythological aspects as well as some others.

(a) In the Kiswahili tradition most if not all classical poetic compositions have a fixed formulaic beginning and ending. The beginning is invariably a form of self-introduction of the poet, his family and social background and often a statement of his or her artistic qualification. A good example is the opening of the famous classical poem, Inkishafi, composed by Ali Bin Nassir (1720-1820). It starts thus:

Bismillahi naikadimu

Hali ya kutunga hino nudhumu

Na ar-Rahmani kiirasimu

Bas ar-Rahimu nyuma ikaye

(Nassir 1972: 104-105)
I begin in the name of Allah

To compose this poem

And arrange His attributes, God the merciful

God the generous, I will mention, too

The ending formula details the composer's gratitude to God for the ability to complete the composition and also serves as a way of signing off by praying for blessings upon the reader as well as calling on 
the latter to kindly effect any necessary corrections on the work. The Inkishafi ends in these words:

Sasa takhitimu tatia tama

atakofuata na kuyandama
I will now end here and put a stop

Whoever shall heed these words and stick to them

tapata khatima na mwisho mwema Will be blessed till his or her life's end

Rabbi hukuomba, tujaaliye

May God Almighy grant us this prayer

Rabbi mrahimu mwenye kutunga May the Lord shower blessings upon the composer

na mezokhitimu, mja malenga

Sala na salamu ni zao kinga

Rabbi takabali ziwashukiye
And the poet who has brought the work to an end

May God's blessings and peace be their shield

May your Divine care be upon them

(Nassir 1972: 104-105)

(b) Stylistically, epic poems make use of repetition which is a deliberate device for stressing and achieving certain desired linguistic and literary effects. The lines and stanzas of Utenzi wa Liyongo are full of examples of the use of this skill. Perhaps the aim of the use of repetition in oral poetry was to serve as a mnemonic aid in recalling the line of the story. For instance, when Liyongo escapes from jail, the poet aptly captures the panicky mood at the palace as the attendants and other functionaries busy themselves with the task of attracting the prisoner to join the dance so that they may trap him. We are told that,

Ngoma na nyingi kusi

kusisalie unasi

ikawa kama harusi

watu wakiangaliya

Wote wakakutanika mahala pakatandika na uzuri wakaweka deuli na subahiya
With drums and hand-claps

All at once

Celebration like at a wedding

And people watched

They all gathered

They prepared the ground

The ground was spread

With silken wraps 
Wakatandika na zari

na nzuri za hariri

wakaimba mashairi

ngoma kusi kwa umoya

Na mashairi ni haya

Walokwimba kwa umoya

na watu walipokeya

na Liyongo yu pamoya

(Harries 1962)
They spread golden linen

And also silken cloth

They sang poetry

As they clapped and drummed

These are the poems

They sang in unison

The people sang in chorus

And behold! Liyongo was with them

The use of wote, pamoya as well as the successive tense marker $k a$, is deliberate to emphasize the spontaneous reaction and the state of mind of the sentries and the royal. The excitement at the prospect of re-capturing the haunted poet is pitch-high.

(c) The rest of the epic principles outlined by Dundes are also clearly represented in Utenzi wa Liyongo: concentration of the entire story on a single hero character; the existence of an antithetical to the protagonist; the principle of direct contrast and opposition between the hero and the adversary; the death of the hero through betrayal by a villain. In the case of Utenzi wa Liyongo, Liyongo is the folk hero who meets opposition from the ruling Sultan Daudi Mringwari but manages to survive only to die at the hands of his beloved son who betrays him to the Sultan.

\section{CONCLUSION}

The most important question is, what relevance, if any, does this famous Swahili classical epic have for the society today? "One of the most important functions of folklore is its service as a vehicle for social protest. Whenever there is injustice and social oppression, one can be sure that the victims will find some solace in folklore" (cited in Dundes 1965: 308). It is clear that Fumo Liyongo was largely treated as a hero by his kinsfolk because his struggle to the throne of the Pate sultanate symbolised their collective urge to rid themselves of an evil and dictatorial leadership. This is the light in which the poem must be read and interpreted. Today, the epic of Liyongo can be described as a "dramatic account of heroism, wit and strength" (Makokha 2000). Although related in the past tense and referring 
to events that happened long ago and are surrounded by archaism and mystery, the story is "believable and identifiable with contemporary socio-political set-up. This is a story of heroism, patriotism and humanness" (Ibid.). Liyongo's epic is therefore a rich blend of folkloric and historical elements whose theme and story can not be wholly constrained by time or space.

\section{References}

Allen, J. W. T. 1971. Tendi. Nairobi: Heinemann.

Dundes, A. 1965. The Study of Folklore. London: Prentice-Hall.

Harries, Lydon 1962. Swahili Poetry. London: Oxford University Press. Johnson, M. 1992. Lore: Capturing Traditional Knowledge. Ottawa: International Development Research Center.

Knappert, Jan 1979. Four Centuries of Swahili Verse: A Literary History and Anthology. Nairobi: Heinemann.

Makokha, K. 2000. Revered Kiswahili Heroic Epic on Stage. Daily Nation, Nairobi, July 2, p 31.

Nassir, Seyyid Abdalla bin Ali 1972. Inkishafi. Nairobi: Longman.

Okpewho, I. 1983. Myth in Africa. London: Cambridge University Press.

Richard, M. (Ed.) 1973. Folklore and Traditional History. The Hague: Mouton.

Were, Gideon 1971. East Africa Through a Thousand Years. Nairobi: Heinemann. 